\title{
Technological sustainability of industrial enterprises in intellectual infrastructure theory framework
}

\author{
Elena Yakovleva $^{1, *}$ and Alexander Miller $^{2}$ \\ ${ }^{1}$ Omsk State Technical University, 644050 Omsk, Russia \\ ${ }^{2}$ Dostoevsky Omsk State University, 644053 Omsk, Russia
}

\begin{abstract}
The paper presents research findings in the field of the intellectual infrastructure theory for technological development of industrial enterprises. The main scientific result is the development of the content and structure on the concept of intellectual infrastructure for technological development in the system of global innovation and scientific and technological management at the enterprises of the national industry in order to accelerate the transition to intellectual production technologies. A structure and production approach acts as the main theoretical and methodological tools of the forming concept on intellectual infrastructure of technological development. The original features of this approach relate to some aspects. The first one is target orientation to resource requirements of technological development at industrial enterprises, namely, effective intellectual and infrastructural support of all development stages. The stages are aimed at achieving the required level of industrialization. The next is universality in relation to industrial enterprises of different economic sectors. Another aspect is predetermination by the conditions of modern technological evolution. The criterion for effectiveness of the intellectual infrastructure in technological development in the form of technological stability of industrial enterprises is developed and proved. This criterion is considered as a conceptual element in the theory of intellectual infrastructure of technological development and supplementation for the infrastructure based on interdisciplinary links between management (personnel management) and economics, organization and management of enterprises, industries, and complexes of industry. Intellectual infrastructure of technological development provide conditions for the development of sustainable economic links between participants in the process of production.
\end{abstract}

\section{Introduction}

Modern industrial enterprises operate under the influence of a large number of multidirectional and, mostly, disordered factors. In their operation, they focus on the economic results of their activities, which largely depend on the availability of modern

*Corresponding author: elenav12@yandex.ru 
technical and technological facilities. They are based on modern advanced production technologies in the developing technological mode of new industrialization (postindustrialization) $[1,2,3]$. Thus, the greater research interest is in the organizational and economic factors that can provide technological development for industrial enterprises and the technological equilibrium in the elements of its intellectual infrastructure $[4,5]$. In this context, the insights of the key parameters of the technological development infrastructure become actual. This interaction is based on technological links, ensuring the implementation of common interests and strategic objectives of intellectual and innovative development.

In general, the inability to ensure effective technological development of industrial enterprises in the new economic conditions based on traditional approaches determines the central scientific idea of the study. These approaches were developed for the conditions in which modern high-tech enterprises of innovative type no longer perform their activities. The central idea of this study involves the development of the theory of technological development. The ideas of structural functionalism by Durkheim D. E., Parsons T., and Smelser N. are the scientific foundation of this approach. They consider the economy through the prism of a social system that aims for technological development by performing the functions of adaptive behavior in the external environment, achieving the set goals, internal coordination and integration with preservation of patterns, i.e. reference points. This foundation can be successfully applied in the modeling of production and technological system of innovative type. To do this, it is proposed to focus on the trend transformations of the scientific and technological component in the production system and to identify the most significant points of growth that determine the capital investment efficiency and the investment attractiveness of the research and development sector.

\section{Materials and methods}

The key provisions of such scientific directions as intellectualization of the economy, institutional economics, management (innovation management, technology management), personnel management (innovative personnel management, developing personnel management) served as the basic methods of research. General scientific methods and special methods of infrastructure and production approach are applied at the junction between these directions. The method of generalization is used to identify the main characteristics of the intellectual infrastructure for technological development of industrial enterprises. The method of classification was aimed at studying the intellectual infrastructure of the technological development at the industrial enterprise. The method of reasoning was applied as a basis for the system-forming elements of the intellectual infrastructure for technological development in the national economy and the parameters for the intellectual infrastructure of technological development. Analytical and graphical methods were used to estimate the share of productive forces in the leading high-tech countries using the example of the USA and Russia, as well as the share of countries in high-tech exports.

\section{Results}

The framework of this study includes a conceptual model of the intellectual infrastructure of technological development, which is grounded on the infrastructural and reproduction approach. This approach implies that the intellectual infrastructure of technological development at industrial enterprises is seen as a systematic process of combining modern advanced technologies and intellectual assets at all technological stages from product 
manufacturing, production components and intelligent control systems to smart solutions and interconnected digital services. The author's position in the research methodology of intellectual infrastructure for technological development of industrial enterprises comes from a number of axiomatic theses that postulate the key idea of the need to ensure the program-targeted reproduction of the intellectual potential of highly professional employees of industrial enterprises, with this key idea uniting these theses. The basic axiom is the thesis that the sense-making origin of the intellectual improvement of human resources in modern industry is education and morality, determining the internal values of individuals, forming the moral norms of their economic behavior in the process of production activities focused on technological development. The proposed infrastructure-production approach is based on the following methodological foundations (Fig. 1.). The first is a refined methodological basis in the form of synthesis of developmental and innovative approaches to personnel management, as well as approaches to managing the intellectual potential of personnel and intellectual capital. The next is the author's reproductive interpretation of the personnel intellectualization as the basis for the formation of intellectual infrastructure in combination with the above basic axiom of the study. Another one is the influence of socioeconomic prerequisites and factors due to the new megatrend in the form of developing post-industrial technological mode of the sixth generation.

The specifics of the intellectual infrastructure for the technological development at industrial enterprises obtained in the study provides an opportunity to identify the main characteristics of the infrastructure proposed for development (Table 1), as well as the structural relationship of its elements (Fig. 2).

Table 1. The main characteristics in the intellectual infrastructure of technological development at industrial enterprises.

\begin{tabular}{|l|l|}
\hline Type of characteristics & \multicolumn{1}{c|}{ System characteristics } \\
\hline 1. Meaning and content & $\begin{array}{l}\text { Infrastructure of formation and development of intellectual } \\
\text { resources based on the priorities of technological development } \\
\text { at industrial enterprises in the conditions of digital economy }\end{array}$ \\
\hline 2. Life cycle stage & Formation and development \\
\hline $\begin{array}{l}\text { 3. Interaction with the } \\
\text { environment }\end{array}$ & $\begin{array}{l}\text { Open: functioning involves the use of intellectual resources at } \\
\text { the input and innovative products (services) at the output }\end{array}$ \\
\hline $\begin{array}{l}\text { 4. Degree of adaptation } \\
\text { to the external } \\
\text { environment }\end{array}$ & Adaptive flexibility \\
\hline 5. Organization level & Complex, structural, hierarchical \\
\hline 6. Controllability level & Controllable \\
\hline $\begin{array}{l}\text { 7. Dependence on } \\
\text { random events }\end{array}$ & $\begin{array}{l}\text { Probabilistic, since the functioning occurs under the action of a } \\
\text { large number of random factors, it is necessary to have a } \\
\text { relatively clear idea on the sources of random effects }\end{array}$ \\
\hline $\begin{array}{l}\text { 8. Pattern of behavior } \\
\text { over time }\end{array}$ & $\begin{array}{l}\text { Dynamic (dynamism is due to the possibility of acquiring new } \\
\text { qualities and transition to a new state) }\end{array}$ \\
\hline $\begin{array}{l}\text { 9. Discontinuity over } \\
\text { time }\end{array}$ & $\begin{array}{l}\text { Continuous (state of monitored control parameters can be } \\
\text { evaluated at any time) }\end{array}$ \\
\hline
\end{tabular}




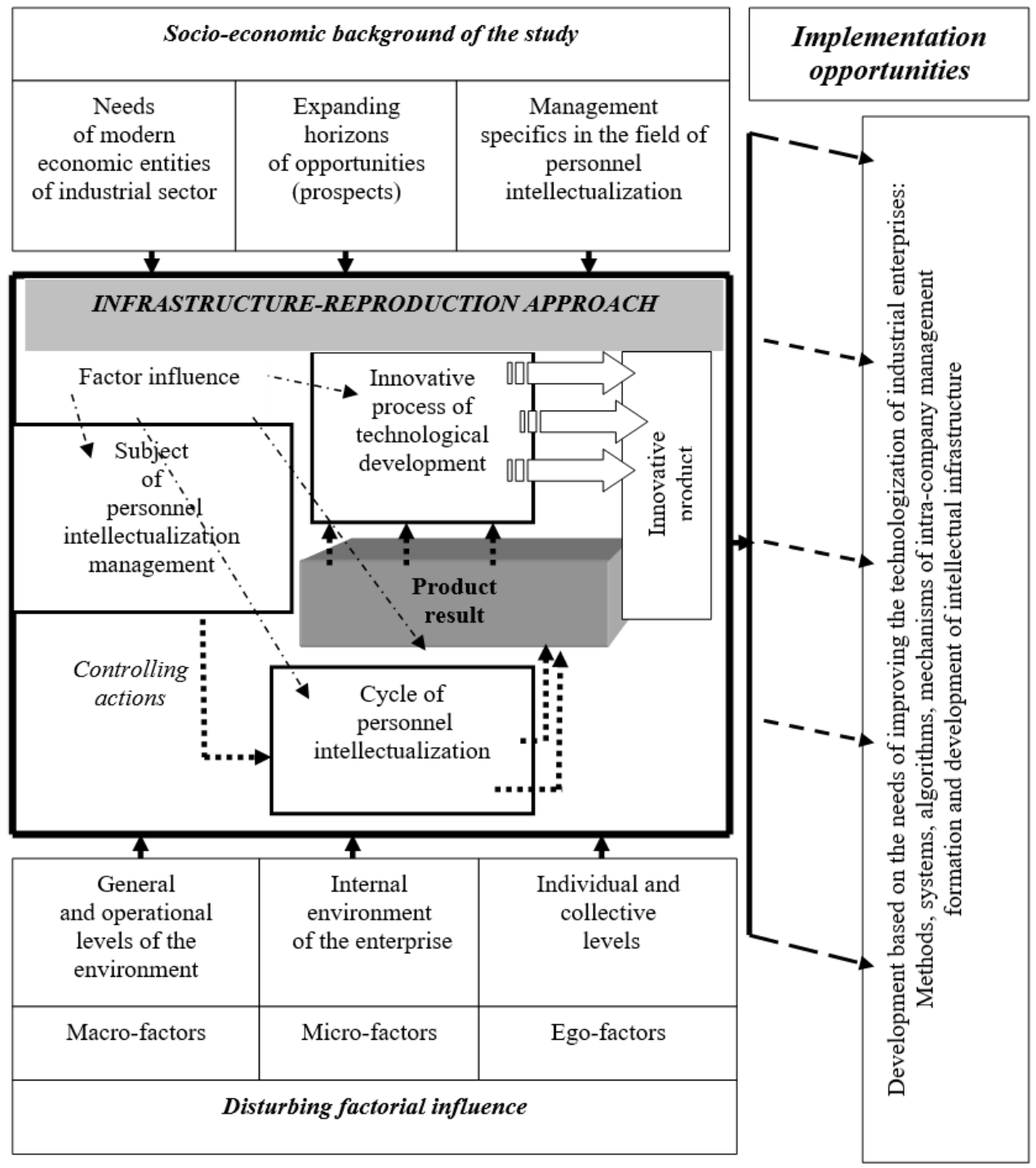

Fig. 1. Process of forming the infrastructure-reproduction approach and its conceptual essence.

The specifics and novelty of the proposed infrastructure-reproduction approach are associated primarily with the reproductive interpretation in the intellectualization of industrial enterprises personnel at the current stage of technological development. This stage assumes the inclusion of this reproduction process as a service support in the cycle of enterprise technologicalization on an innovative basis, thus providing intellectual support for innovative processes in the technological development of industrial enterprises.

The holistic view on the specifics of the intellectual infrastructure of technological development enabled us to determine the conceptual elements revealing the content of the specifics. The infrastructure and production approach are applied as the main theoretical and methodological tool for the concept of intellectual infrastructure of technological development. The system-forming elements of the intellectual infrastructure of technological development in the national economy are shown in Table 2. 


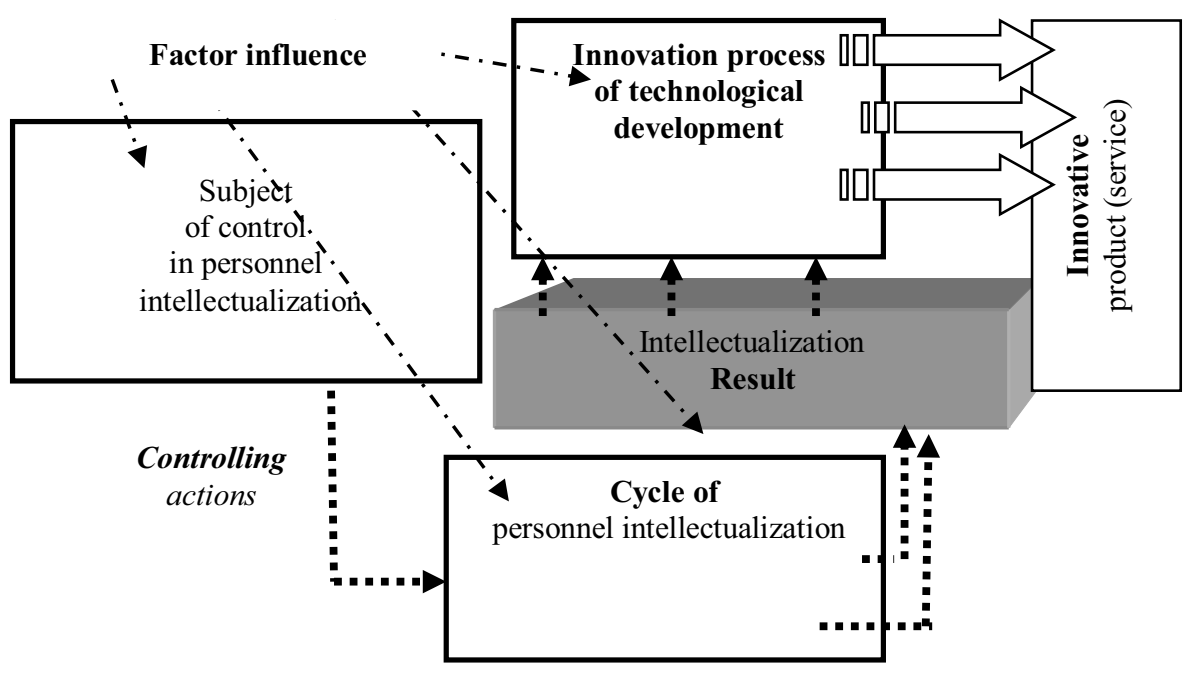

Fig. 2. Intellectual infrastructure of technological development of an industrial enterprise.

Table 2. System-forming elements of the intellectual infrastructure of technological development in the national economy.

\begin{tabular}{|l|l|}
\hline \multicolumn{1}{|c|}{ Element name } & \multicolumn{1}{c|}{ Element content } \\
\hline Object & $\begin{array}{l}\text { System of production and technological links aimed } \\
\text { at regulating the flow of production resources and } \\
\text { technologies }\end{array}$ \\
\hline Subject & $\begin{array}{l}\text { Participants of the intellectual infrastructure of } \\
\text { technological development }\end{array}$ \\
\hline $\begin{array}{l}\text { Subject (area of potential } \\
\text { change) }\end{array}$ & $\begin{array}{l}\text { Production technologies and nanotechnologies of } \\
\text { industrial enterprises }\end{array}$ \\
\hline Purpose & $\begin{array}{l}\text { Making intellectually oriented progressive } \\
\text { technologies }\end{array}$ \\
\hline Fundamental principles & $\begin{array}{l}\text { Achieving a dynamically sustainable intellectual } \\
\text { infrastructure of technological development }\end{array}$ \\
\hline Functions & $\begin{array}{l}\text { Clarifying the focus of the intellectual infrastructure } \\
\text { of technological development }\end{array}$ \\
\hline
\end{tabular}

The system of production and technological links aimed at regulating the flow of production resources and technologies is considered as an object of intellectual infrastructure formation. The participants of the intellectual infrastructure of technological development are the subject of formation in this case. The role of the subjects in the technological development infrastructure of the industrial enterprise involves the formation of working capital, a significant renewal of the factors of production, materials and supplies, qualified personnel, turnover acceleration due to the sales of manufactured products to consumers. The subject of formation is the transition to intellectual production technologies. This transition has defined the conceptual goal of forming the intellectual infrastructure of technological development, aimed at creating intellectually oriented progressive technologies. The content of the fundamental principles of the concept is focused on achieving the dynamically sustainable functioning of the intellectual infrastructure of technological development. The underlying principles of the intellectual infrastructure of technological development are the principles of acceptable risk, systematic consideration of the relationships and interdependencies in relation to the aggregate aspects of the study object, a comprehensive generalized study of the existing problems. These principles also include multivariate development of comprehensive alternative scenarios to 
eliminate crisis phenomena, enhancing the competitive positions of participants in the intellectual infrastructure of technological development, achieving the criteria of effectiveness and efficiency of optimal interaction procedures. These principles are targeted at the specific objectives in the development of intellectual infrastructure of technological development, and they create the premises for the use of the project-targeted approach. The functional elements of the concept reveal the focus of action on the formation and development of the intellectual infrastructure of technological development. Altogether, and in interaction, the functions reflect the purpose and role of the intellectual infrastructure of technological development as a system of economic relations, which are part of the system of production relations. The key focus of the functions in the intellectual infrastructure of technological development is to implement specific economic links between all participants in the intellectual infrastructure of technological development. Specific links between the participants in the intellectual infrastructure of technological development are realized through a system of contracts, agreements on the production and sales of products. In certain cases, based on emerging demands and available solvency, the volume of production and consumption of nomenclature types of commodities is specified. Thus, economic ties are refined, replenished, and become more flexible, specifying the interests of each of the participants in the intellectual infrastructure of technological development. This approach takes into account the full range of market attributes, namely, the presence of demand, existing supply, the prevalent pricing policy and others.

The intellectual infrastructure of technological development is not static in its essence $[6,7]$. In its most general form, the development of intellectual infrastructure can be represented by the following parameters (Fig. 3). This does not exclude the need to define quantitative and qualitative assessment indicators for the result of the intellectual infrastructure of technological development. The planned ratios between the results achieved and the funds spent will determine the effectiveness of the intellectual infrastructure of technological development.

\begin{tabular}{|c|c|c|c|}
$\begin{array}{c}\text { Sources of } \\
\text { development: } \\
\text { production- } \\
\text { innovative and } \\
\text { technical- } \\
\text { technological } \\
\text { environment }\end{array}$ & $\begin{array}{c}\frac{\text { Development }}{\text { conditions: }} \\
\text { product specifics, } \\
\text { degree of resource } \\
\text { utilization, } \\
\text { technical facilities } \\
\text { structure, level of } \\
\text { personnel qualification }\end{array}$
\end{tabular}$\longrightarrow \begin{gathered}\frac{1}{\text { Development }} \\
\text { result: } \\
\text { Modern innovative } \\
\text { and progressive } \\
\text { technologies, profit, } \\
\text { etc. }\end{gathered}$

Fig. 3. Parameters for development of intellectual infrastructure of technological development.

To summarize, we should state that the intellectual infrastructure of technological development in the system of global management of innovation and scientific-technological activity creates conditions for the development of sustainable economic relations between the participants of the production process. These relations are aimed at bringing the manufactured products to the ultimate customers and making a profit. The above defines an insight of the intellectual infrastructure of technological development as a set of relations that arise objectively between participants of technological development, including consumers of products, suppliers of all kinds of materials, market intermediaries, state and municipal authorities, and are aimed at achieving financial results from manufacturing products and the implementation of other activities. 


\section{Results discussion}

Unbiased trends in modern technological dynamics are such that they require the introduction of a targeted comprehensive criterion of effectiveness for the formation and development of the intellectual infrastructure of technological development in the form of the criterion of technological sustainability. Such challenges, which determine the causality of such a target, include many of the trends in Industry 4.0 based on the Fourth Industrial Revolution $[8,9,10]$. For example, the comparative technological diversity of productive power in Russia and other subjects of the world economy is shown in Figures 4, 5 (https://rusplt.ru/society/rossiya-uchastnik-novogo-35474.html). Thus, in the USA the share of productive power of the fourth technological mode is $15 \%$, the fifth is $60 \%$ and about $10 \%$ falls on the sixth technological mode. In Russia, the third technological mode is $40 \%$, the fourth is $50 \%$, and the fifth is $10 \%$. The share of the sixth technological mode is negligible.

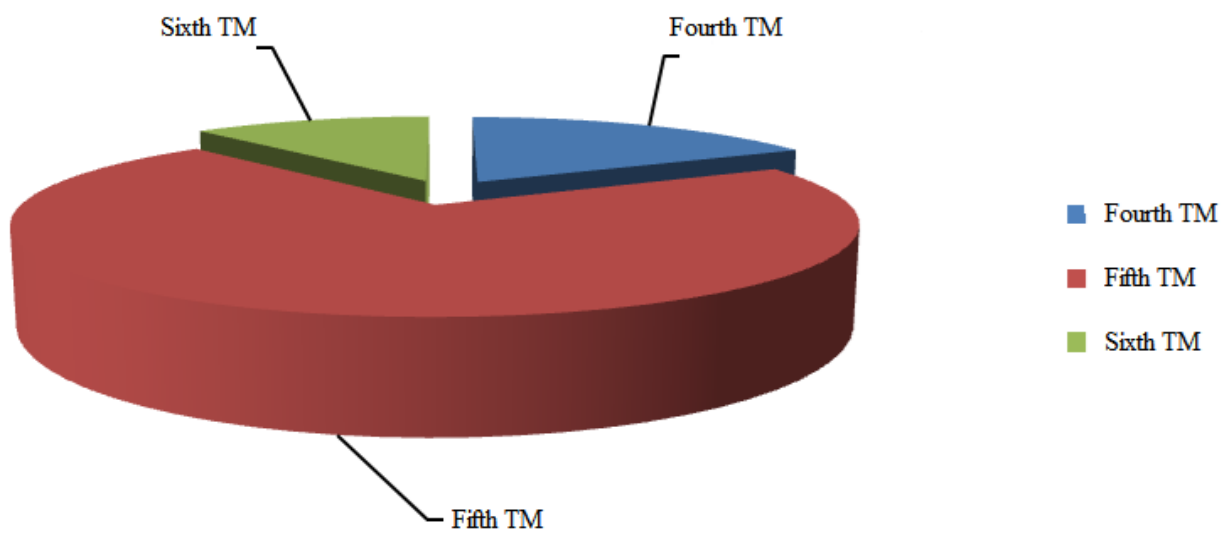

Fig. 4. Productive power of technological modes in the USA in 2018.

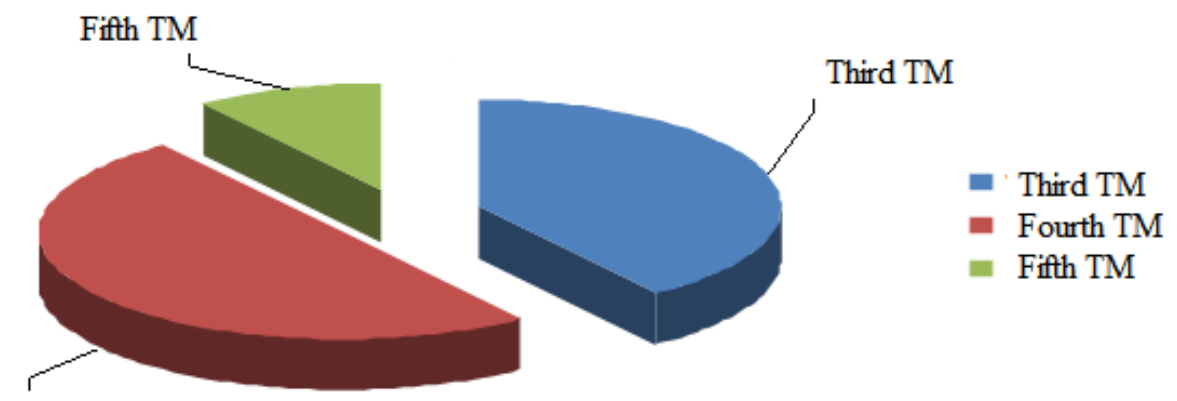

Fourth TM

Fig. 5. Productive power of technological modes in Russia in 2018.

Another challenge of technological sustainability in the process and as a result in technological development is the structure of export of Russia (Fig. 6) (https://rusplt.ru/society/rossiya-uchastnik-novogo-35474.html). The pie-chart shows that almost $2 / 3$ of exports $(64.79 \%$ ) are mineral raw materials and energy resources (oil, gas, petroleum refinery products, coal, mineral waxes, etc.). Metals and their products comprise $9.88 \%$ of the total volume of Russian exports, chemical products amount to $6.09 \%$, 
foodstuffs and agricultural raw materials comprise 5.53\%, machinery, equipment and vehicles are $5.13 \%$, timber and pulp and paper products amount to $3.10 \%$, and the share of precious metals and stones is $2.24 \%$. At the same time, exporting raw materials on the international market is known to be a low-paying and inefficient business. Therefore, the most important strategy of most countries in the world is to increase exports of high-tech products.

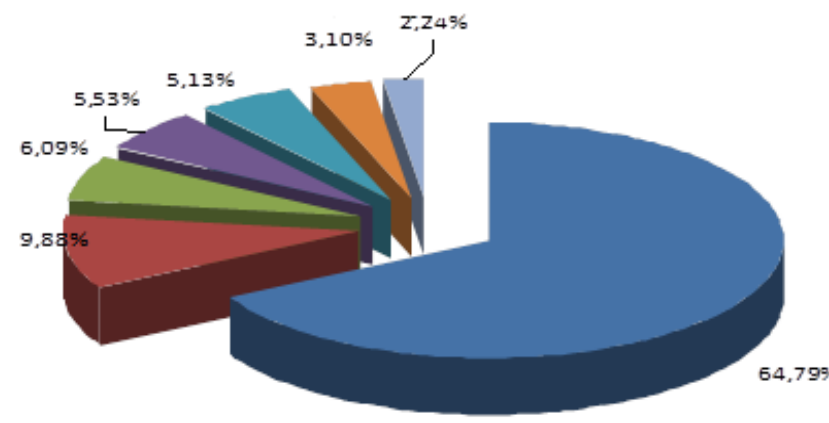

- Mineral products

- Metals and their products

= Chemical products

. Foodstuffs and agricultural raw materials

- Machinery, equipment and vehicles

= Timber and pulp and paper products

$=$ Precious metals and stones

Fig. 6. Structure of export of Russia in 2018.

In turn, the share of various national economies in high-tech exports is shown in Figure 7 (https://rusplt.ru/society/rossiya-uchastnik-novogo-35474.html). China plays a significant role in the global high-tech export market. In 2017, China supplied a quarter of all hightech products with a total of $\$ 654$ billion. Germany and South Korea ranked second and third with $\$ 196$ billion and \$166 billion respectively. Russia's share in global high-tech markets is $0.2-0.3 \%$.

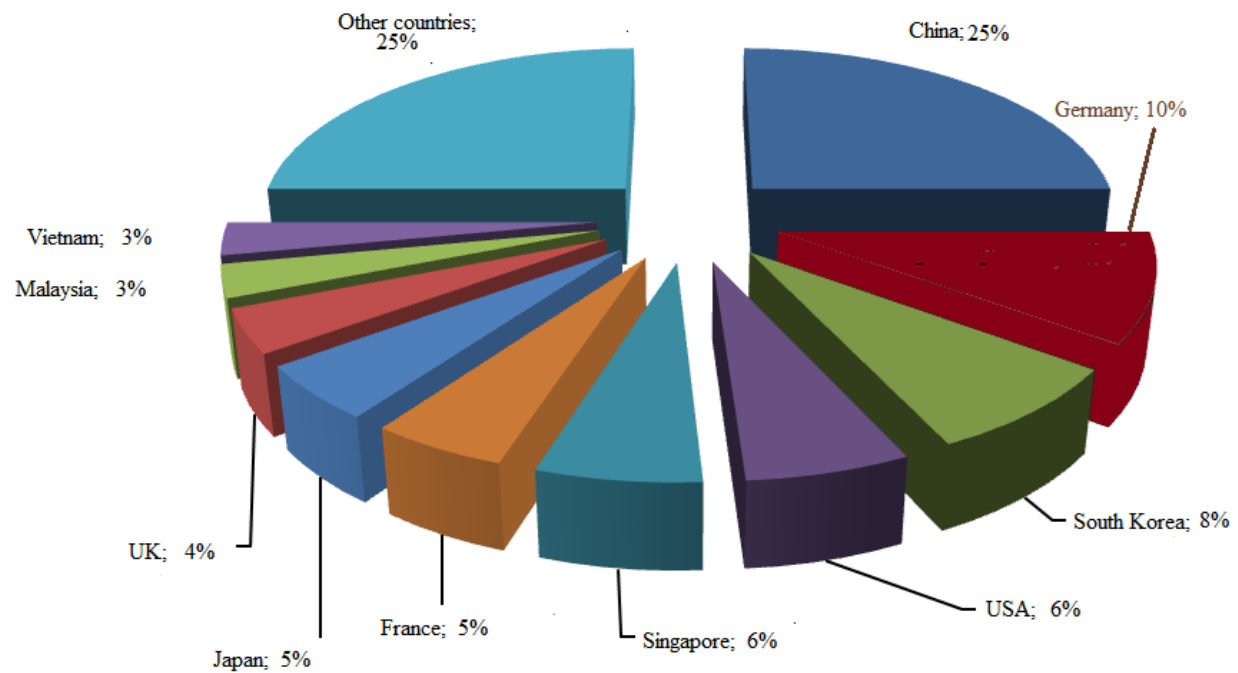

Fig. 7. Share of countries in high-tech exports.

The study of theoretical aspects of technological sustainability brought to certain conclusions about its causal essence, revealing the content of technological sustainability as a criterion of effectiveness in formation and development of intellectual infrastructure of technological development. 
The analysis of various approaches to revealing the concepts of "technological modernization of an industrial enterprise", "sustainable development of an industrial enterprise" proves that the concepts under consideration, although they are analogues, are not able to correctly define the essence and content of the concept "technological sustainability of an industrial enterprise". It is advisable to clarify the content of the concept in relation to the specifics of Russian industrial enterprises and the trends of modern technological dynamics.

It is advisable to take into account and separate these relatively close approaches to understanding the essence of the considered concept. Thus, we propose to define the technological sustainability of industrial enterprises as the ability of the enterprise to perceive the achievements of technological development, to implement them into the production process, effectively apply and improve in the manufacturing and production process to increase the competitiveness of the enterprise and its further technological development. So, following this logic, technological sustainability should attribute to the most important components of economic stability of the industrial enterprise, along with production, financial and information sustainability (Table 3).

Table 3. Technological sustainability as a component of economic sustainability of modern industrial enterprise.

\begin{tabular}{|c|c|c|}
\hline \multirow{4}{*}{ 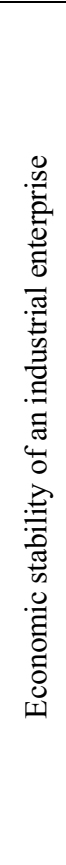 } & Technological sustainability & $\begin{array}{l}\text { The ability of the enterprise to perceive the } \\
\text { achievements of technological development, to } \\
\text { implement them into the production process, } \\
\text { effectively apply and improve them in the process of } \\
\text { manufacturing and production to increase the } \\
\text { competitiveness of the enterprise and its further } \\
\text { technological development }\end{array}$ \\
\hline & Production sustainability & $\begin{array}{l}\text { - production strategy and tactics } \\
\text { - size and structure of production stocks } \\
\text { - better organization of production } \\
\text { - resource availability } \\
\text { - utilization }\end{array}$ \\
\hline & Financial stability & $\begin{array}{l}\text { - financial strategy } \\
\text { - level of financial stability and solvency } \\
\text { - goodwill } \\
\text { - efficiency of financial and investment management } \\
\text { - asset liquidity } \\
\text { - equity capital } \\
\text { - leverage ratio }\end{array}$ \\
\hline & Marketing sustainability & $\begin{array}{l}\text { - marketing strategy } \\
\text { - output of products which are in demand on the } \\
\text { market } \\
\text { - output of products that meet standards } \\
\text { - diversified product range }\end{array}$ \\
\hline
\end{tabular}

\section{Summary and conclusion}

The identified problems of technological development at industrial enterprises [11] with the formation of the sixth technological mode showed the inconsistency of traditional methodological approaches in solving most of the problems. These approaches were formed back in the last century in the previous conditions of economic management. Modern high-tech enterprises no longer operate under those conditions. As a result, the search for adequate methodological solutions was predetermined. These solutions include the generalization and systematization of theoretical, methodological and procedural 
foundations of the intellectual infrastructure of technological development at industrial enterprises in the context of diversification and technological modernization of the Russian economy.

In total, the analysis and systematization of scientific views on the intellectual infrastructure of technological development provide certain conclusions about the level and state of the theoretical groundwork in the studied subject area, as well as a conceptual basis for further theoretical developments.

1. The research areas for only certain aspects of the intellectual infrastructure of technological development with a particular scientific specialization were identified.

2. The problem not having been disclosed in earlier studies in Russia and elsewhere is a holistic view on the intellectual infrastructure of technological development. Moreover, such a view is from the perspective of management, which can reveal the specifics of intellectual infrastructure as an object of management, identify its fundamental features, targets, and methods of management.

3. The preconditions for the development of a new scientific area of research on the intellectual infrastructure of technological development are established. Above all, they are in the field of personnel management (innovative personnel management, development of human resources), and in the field of management (innovation management, technological management, intellectual capital management, resources, products, services etc.).

4. Currently, the theory of intellectual infrastructure of technological development is at the stage of formation with no established terminology. At the same time, multiple aspects of the intellectual infrastructure formation of industrial enterprises are not covered by the studies in the current stage of diversification and technological modernization of the Russian economy. These aspects should take into account the specifics of the reproductive balance for the intellectual resources of personnel in the innovation sphere of modern industrial enterprises.

5. The conceptual framework of the intellectual infrastructure of technological development is formed, assuming the technological sustainability of industrial enterprises as a criterion of infrastructural efficiency.

\section{Acknowledgment}

The reported study was funded by RFBR, project number No.20-010-00080

\section{References}

1. P. Ghisellini, S. Ulgiati, J. Clean. Prod. 243 (2020) DOI: 10.1016/j.jclepro.2019.118360

2. A. Papageorgiou, A. Fernandez-Fernandez, S. Siddiqui, G. Carrozzo, Comp. Comm. 149, 232-240 (2020) DOI: 10.1016/j.comcom.2019.10.024

3. A. Corallo, M. Lazoi, M. Lezzi, Comp. in Ind. 114 (2020) DOI: 10.1016/j.compind.2019.103165

4. N. Crespo, D. Aurelio, Eur. J. Int. Manag. 14(1), 28-54 (2020) DOI: 10.1504/EJIM.2020.103796

5. J. Lockwood, Y. Song, Int. J. Bus. Comm. 57(1), 113-144 (2020) DOI: $10.1177 / 2329488416675841$

6. J. Chin, V. Callaghan, S. Allouch, J. Amb. Intell. Smart Env. 11(1), 45-69 (2019) DOI: 10.3233/AIS-18050 
7. B. Asheim, Innov.-Eur. J. Soc. Sc. Res. 32(1), 8-25 (2019) DOI: 10.1080/13511610.2018.1491001

8. A. Polido, S. Pires, C. Rodrigues, F. Teles, J. Clean. Prod. 240 (2019) DOI: 10.1016/j.jclepro.2019.118224

9. S. Guillemot, H. Privat, J. serv. Market. 31(7), 837-850 (2019) DOI: 10.1108/JSM-122018-0361

10. X. Cai, Y. Qian, Q. Bai, W. Liu, J. Comput. Appl. Math. 367 (2020) DOI: 10.1016/j.cam.2019.112457

11. E. Kahiya, Int. Bus. Rev. 29(1) (2020) DOI: 10.1016/j.ibusrev.2019.101621 